\title{
The socio-economic context of Capernaum's limestone synagogue and Jewish-Christian relations in the late-ancient town
}

\author{
Wally V. Cirafesi
}

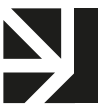

VERTAISARVIOITU

KOLLEGIALT GRANSKAD

PEER-REVIEWED

DOI: https://doi.org/10.30752/nj.102988

AвSTRACT - In this article, I consider a set of contextual questions related to the social and economic influences on the construction and use of Capernaum's great limestone synagogue, and ask what these influences might tell us about Jewish-Christian relations in this village during the fifth and sixth centuries CE. After a survey of current scholarship, I address issues of method and engage in the interpretation of the relevant primary sources, some of which have only very recently been discovered, while others have been overlooked in discussion of the question, or are deserving of reinterpretation. Building upon previous proposals, and in places revising them, I argue that we should see a dynamic interplay at work between local and non-local sources of funding for the synagogue and an intensely interactive and relational setting for the town's Jews and Christians.

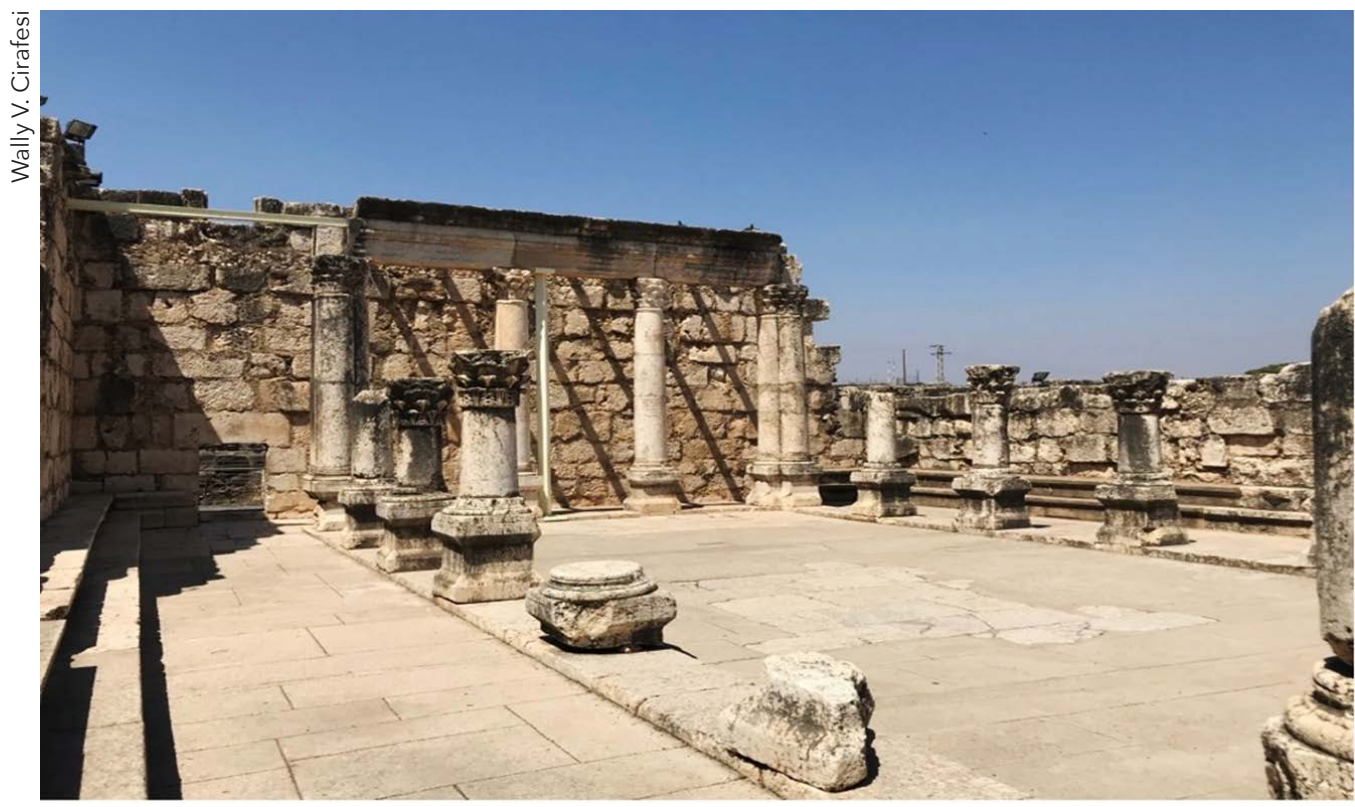

Fig. 1. Main hall of the limestone synagogue, looking NE. 


\section{Introduction}

In the summer of 1838 , the American explorer Edward Robinson and his travelling companions came to the ruins of Tell Hum, a village resting just off the north-west shore of the Kinneret Lake and today firmly identified as the site of ancient Capernaum known from the New Testament as the hometown of the Apostle Peter and a centre of activity for Jesus of Nazareth (see Robinson I84I: 288-30I, esp. 297-8). ${ }^{1}$ While Robinson described the

1 Jonathan Reed (2000: I42) mistakenly claims that Tell Hum was not properly identified as Capernaum until I 866 upon the expedition of Charles Wilson. But Robinson himself notes (I84I: 300-I) that Tell Hum had a centuries-long tradition of being regarded as ancient Capernaum, including by some of his contemporaries, most notably John Wilson, who published his travel log in 1847 , nearly twenty years before Charles Wilson (J. Wilson I 847: I43). As time has shown, Robinson, for his part, wrongly rejected Tell Hum as the site of Capernaum. Rather, he argued at length in his I 84I publication (Robinson I84I: 288-95) and then again in 1856 (Robinson I856: 348-58), that Capernaum should be identified with the nearby site of Khirbet al-Minya. Although Robinson never lived to know it, his theory was definitively disproved in 1937, when the German archaeologists Alfons Maria Schneider and Oswin Puttrich-Reignard uncovered an Umayyad mosque at Khirbat al-Minya, making it clear that the remains Robinson had seen almost a century earlier and the grand complex Schneider and Puttrich-Reignard had been digging out since 1932 were, in fact, an early Islamic palace that rendered no pre-Islamic remains (see Schneider I 952: 23-45; and more recently Kuhnen 20I4). This discovery made the identification of Khirbet al-Minya as ancient Capernaum impossible and strengthened Capernaum's identification with Tell Hum. The most recent full-scale argument for identifying Tell Hum as Capernaum is in Laughlin I989: $19 \mathrm{I}-9$. place as, on the whole, 'desolate and mournful', he quickly and clearly recognised the remarkability of the ruins themselves. One set of remains drew his particular attention: 'Not far off,' he says, 'are the prostrate ruins of an edifice, which, for expense of labour and ornament, surpasses anything we had yet seen in Palestine' (Robinson I84I: 298). That summer in 1838 , he supposed that these elegant ruins, consisting mainly of compacted limestone, had once formed the structure of either a church or a 'heathen' temple (ibid. p. 299). ${ }^{2}$ However, upon a second expedition in May of I 852 - fourteen years after his initial visit and after having seen the comparable 'Jewish remains' at Kefar Bar'am and Meiron - Robinson changed his mind and became the first to conclude that the edifice at Tell Hum was a synagogue: 'The edifice therefore was once a Jewish synagogue, apparently of unusual size and magnificence; surpassing everything of the kind, which we saw elsewhere' (Robinson I 856 : 346 ; see fig. I). ${ }^{3}$

2 As did J. Wilson (I 847: I43).

3 The fact that Robinson was the first to identify this building, as well as other buildings in Galilee, as synagogues is noted also by Heinrich Kohl and Carl Watzinger (I9I6: I): 'Die antiken Ruinen, deren Aufnahmen hier veröffentlicht warden, sind zuerst I 852 von Eduard Robinson auf Grund der hebräischen Inschriften und der Übereinstimmung ihrer Architektur als Synagogen bezeichnet und mit der Blüte der jüdischen Schulen in Galiläa in Zusammenhang gebracht worden.' Worth noting here also is that it was not until I 894 that the ruins of Tell Hum came under the formal control of the Franciscan Custodia Terrae Sanctae, which purchased the land from the Samakieh Bedouin tribe. According to the Custodia's own account, its purchase of the Capernaum ruins almost I 25 years ago was the result of a long and complicated process in which various Christian groups competed with each other and with 'the Jews' to acquire 
As subsequent excavations throughout the twentieth century only confirmed, Robinson's identification of Capernaum's great limestone building as a synagogue is beyond doubt. ${ }^{4}$ Yet

the property (Custodia Terrae Sanctae website). See also Becker 20 I 5: I I 3-39 (esp. I I 3-I9) for a helpful discussion of Robinson's efforts within the context of the emerging discipline of 'biblical archaeology' in the nineteenth century.

4 Excavations and restorations of the building - first only partially by Charles Wilson in the I86os, and then more systematically by Heinrich Kohl and Carl Watzinger in I 905 , Wendelin von Menden from I 906 to I 91 5, and Gaudenzio Orfali from I 922 to I 925 - established the identity of the building as a synagogue with certainty well before the Franciscan archaeologists Virgilio Corbo and Stanislao Loffreda began their large-scale excavations in I969. A menorah inscribed on a capital and the image of a portable Torah shrine carved on a slab of limestone were found among the building's architectural remains. The structure itself was clearly a public building meant for large gatherings - Chad Spigel (2012: I75) suggests a seating capacity of approximately $600-700-$ in a town that had a Jewish population well into the sixth century CE. On Capernaum as a predominately Jewish village in the first century, see Chancey 2002: IoI-5; Mattila 20 I 5 : 21 7-57. On a Jewish population in Capernaum in the fourth century, see Runesson 2007: 23 I-57; Arubas and Talgam 2014: 237-74. The fourth-century Christian heresiologist Epiphanius (Panarion 30.I I. Io), indicates that, in the time of his contemporary Joseph of Tiberius (d. $c$. $356 \mathrm{CE}$ ), there were no non-Jews living in Capernaum (as well as in Tiberias, Sepphoris, and Nazareth). On the continued presence of Jews in Capernaum in the sixth century, see the midrash Qobelet Rabbah I:8 (redacted 6th-8th cent.), which, even if a rabbinic caricature, represents a polemical interaction between rabbinic Jews ( $R$. Joshua and his nephew) and Capernaum's minim, that is to say non-rabbinic Jews. See also the sixth-century donor inscription on the mosaic pavement of the synagogue at several historical questions - or what Zvi Uri Ma'oz has called 'discrepancies' (Ma'oz I 999: I 37) - about the building's origins and socioreligious context continue to be debated, not least because the remains of a Byzantine octagonal church stand a mere twenty-five metres away (see figs. 2 and 3). The dating of the limestone synagogue was, from the late I 960 s to the early 2000 , certainly the most contentious of these questions, with classical art-historians arguing for a date in the second or early third century based on the synagogue's architectural style, and archaeologists arguing for a much later date based on the building's stratigraphy. ${ }^{5}$ While there is perhaps not quite a consensus yet, scholarship over the course of the past twenty years has increasingly affirmed a date in the late fifth or sixth century. ${ }^{6}$

Hamath Gader mentioning a Jewish man named 'Yosse bar Dosti of Capernaum' (Naveh I 978: no. 33; Foerster I 995: 87-94, 90-I). Arubas and Talgam (201 4: 246) date the inscription to the fifth century based on 'the synagogue's mosaic floor, its architectural characters as well as other stratigraphic and epigraphic evidence', but this contradicts Gideon Foerster, who notes the stratigraphy dates the synagogue, as well as the mosaic pavement, to the sixth century. See below for more discussion of this mosaic inscription.

5 The essence of this debate is captured in the interchange between Jodi Magness, James F. Strange, and Eric M. Meyers in Avery-Peck and Neusner 200r. See also the surveys in Runesson 2007; Tarkhanova 2021.

6 In the early and mid-twentieth century, the broad consensus was that the limestone building dated to the second or third century $\mathrm{CE}$, a view based mainly on stylistic analysis of the synagogue's decorative programme. However, in the late r 96os and early i 970 , Virgilio Corbo and Stanislao Loffreda challenged the consensus view in favour of a latefourth-century or fifth-century dating on the basis of the stratigraphic analysis that resulted from their systematic excavations underneath 
Adopting this late-fifth/sixth-century dating, I wish to consider in this article a set of contextual questions related to the social and economic influences on the synagogue's construction and use, and to ask what these influences might tell us about Jewish-Christian relations in Capernaum during this period.

\section{Current scholarship}

Analyses of the social and economic influences on the construction of Capernaum's limestone synagogue have generally fallen into two camps, revolving around arguments for either a local or non-local source of patronage. Until recently, it was more common for scholars to assert the non-local origins of the synagogue's sponsorship, mainly because, firstly, of the impression given in Roman legal sources that appear to bar the

the synagogue in 1969 (Corbo I 975: I I 3-69). The terms of the subsequent debate were generally bifurcated along disciplinary lines, with art-historical approaches being pitted against stratigraphic ones. Despite some notable dissent (e.g. Tsafrir I 995) and at least one attempt to reconcile the discrepancy between the artistic style and the stratigraphy of the limestone synagogue (Ma'oz I999), scholarship has generally favoured the latter dating on the basis of archaeological data. In I 997, Loffreda, in fact, revised his own dating of the entire synagogue to the last quarter of the fifth century on the basis of a new study of the coins found in the building (Loffreda I 997: 232-3), and Jodi Magness has argued strongly for a date in the sixth century on the basis of her interpretation of the numismatic and ceramic records (Magness 2001: 22-3; Magness 20I2). Furthermore, in a recent, and in my view quite significant, study, Svetlana Tarkhanova has shown that even the synagogue's decorative style - the main, and really only, data that have traditionally supported the early dating - actually supports the later dating suggested by the stratigraphic evidence, particularly as proposed by Magness (see Tarkhanova 202 I).
Jewish community from building new synagogues (e.g. Theodosian Code r 6:8:25), ${ }^{7}$ and, secondly, the assumption by scholars that such a small and relatively poor town could not have funded such a grand public building. Virgilio Corbo himself, who directed the Capernaum excavations with Stanislao Loffreda over the course of nineteen seasons (1968-86), asserted this view in his 1975 report:
Who was the patron of a synagogue, for which there is not found an equal in wealth and proportions? For an answer we must keep in mind the poverty of the houses of the insulae found up to now in Capernaum in order to understand that, if any private individual had the opportunity to offer some column shaft (such as the one offered by Herod and the other by Alphaeus, son of Zebedee), certainly no one had the financial means to build a monument full of sculptures, with stone brought from afar and whose construction lasted a whole century. (Corbo I975: I69) ${ }^{8}$

Corbo went on to propose that the building might have been funded out of the imperial treasury during a time of renewed sympathy for Jews and Judaism under Julian

7 See Linder I 987: 287-8.

8 The English translation is mine. The Italian text reads: 'Chi fu il mecenate di una sinagoga che non trova l'eguale per ricchezza e proporzioni? Per una risposta bisogna tenere presente la povertà delle case delle insulae ritrovate sino ad oggi a Cafarnao per capire che se qualche privato ha avuto le possibilità di offrire qualche fusto di colonna (come quella offerta da Erode e l'altra da Alfeo, figlio di Zebedeo), certamente nessuno ebbe le possibilità finanziarie per tirare su un monumento ricco di sculture, con una pietra portata da lontano e la cui costruzione durò tutto un secolo.' 


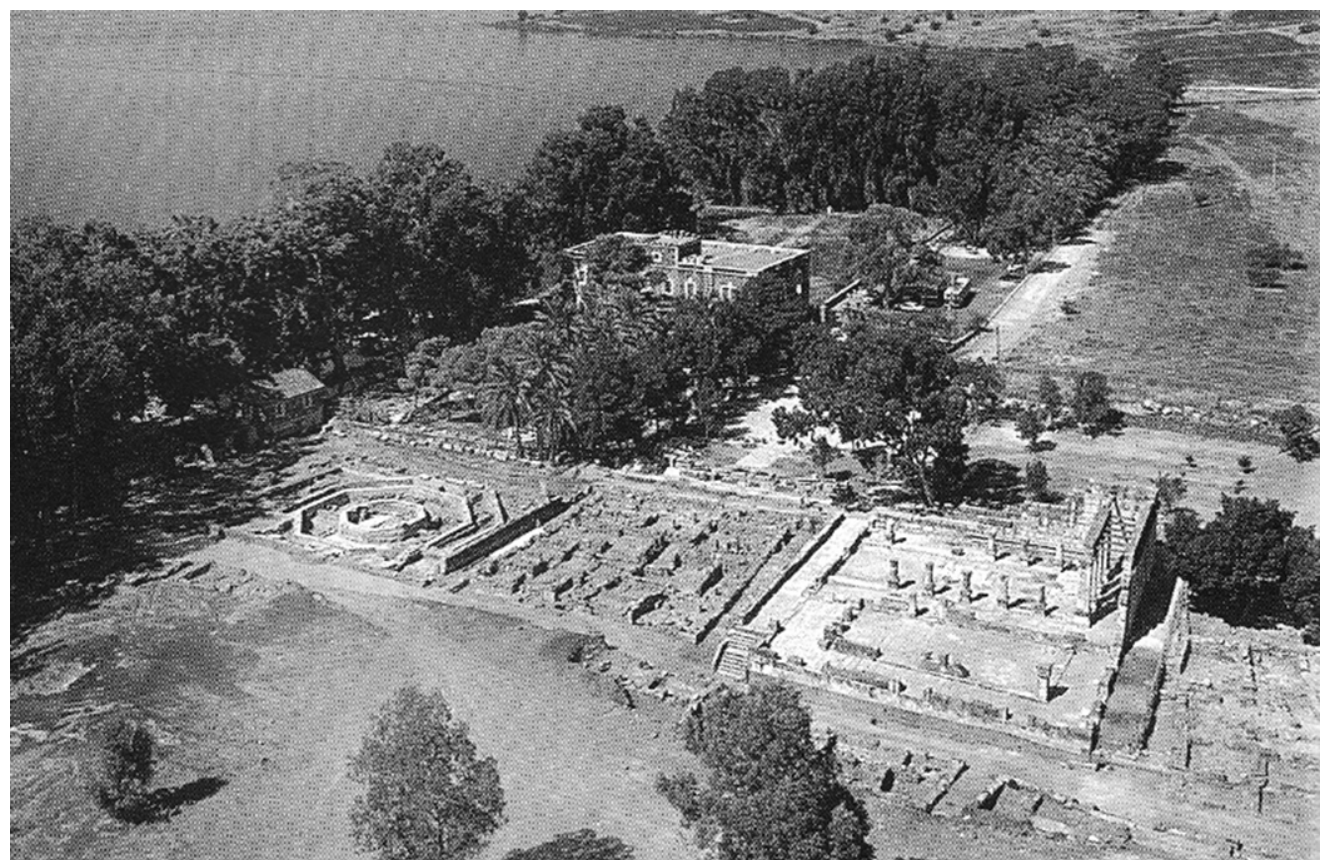

Fig. 2. Aerial photo taken in 1972 of Capernaum's octagonal church and limestone synagogue, with residential Area 2 separating them. Photo from Loffreda 2005: DF 3. Reproduced here with permission.

(36 I-3 CE).9 This proposal, however, went nowhere, probably because it (oddly) conflicted with the late chronology of the building that Loffreda had published as early as I973, which stated the excavators' combined belief that the synagogue was built in 'the last decade of the fourth to the middle of the fifth century' (Loffreda r 973: 37). In I997, Loffreda dated the entire building to

9 'We think of the Roman imperial treasury at the time of Julian the Apostate. History has handed down to us the gestures of sympathy of this emperor in favour of Palestinian Judaism, sympathy nourished by the aversion of this former Christian towards Christ' (translation mine). The Italian text reads: 'Noi pensiamo all'erario imperiale romano ai tempi di Giuliano l'Apostata. La storia ci ha tramandato i gesti di simpatia di questo imperatore in favore del giudaismo palestinese, simpatia nutrita dall'avversione di questo ex cristiano verso il Cristo' (Corbo I 975: I69). the period $475-500 \mathrm{CE}$, further problematising any association of it with the Julianic era and, therefore, with Julianic imperial funding (Loffreda I 997). While Corbo and Loffreda had a lot to say about relations between Jews and the 'Judaeo-Christians' in the pre-fifth century period of Capernaum's history, ${ }^{10}$ neither developed any robust theory on the place of the limestone synagogue in those relations in the fifth and sixth centuries. Their basic assumption remained that 'orthodox' Jews and Byzantine Christians co-populated the village during a time in which Christianity's influence in Palestine was increasing significantly (Loffreda I 993: 30-I).

In I999, Ma'oz asserted that the construction of such a magnificent synagogue so close to a Byzantine church during a period marked otherwise by Christian disdain for

10 On this see period, see the discussion in Cirafesi $202 \mathrm{Ib}$. 


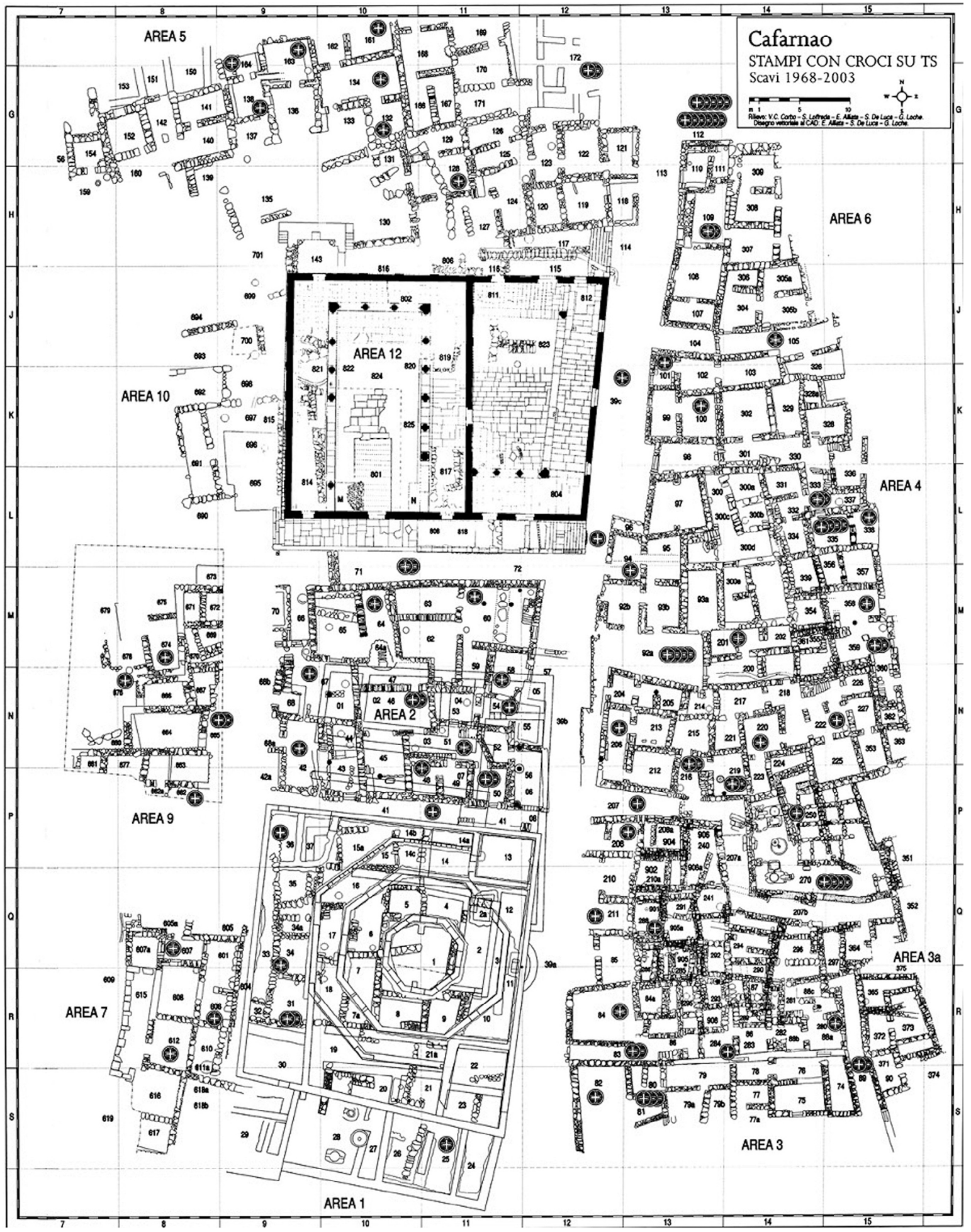

Figure 3. Final town plan of Capernaum from Callegher 2007: 16-17. Reproduced here with permission.

Crosses mark loci in which Late Roman Fine Ware with stamped crosses were discovered. 
the Jewish community and its synagogues, as reflected in the legal sources, created the most challenging 'discrepancy' for the interpretation of Capernaum in late Antiquity (Ma'oz I999: I43-4). Because he was so convinced that Jews and Christians did not 'mix' in villages and smaller settlements in Byzantine Palestine, Ma'oz was compelled to develop a 'radical solution', in which neither local nor non-local Jews had anything to do with the construction of the Capernaum synagogue. Rather, he surmised that there were hardly any Jews in Capernaum by the fifth century, and certainly no Jews with the money and power to build a grand public building out of imported limestone (ibid. pp. I39, I44). $\mathrm{Ma}{ }^{\prime} \mathrm{Oz}$, therefore, suggested that Byzantine Christians, impassioned to make pilgrimage to the 'Holy Land' and backed with imperial money, built the synagogue in the fifth century as a Christian locus sanctus out of spolia from other earlier Galilean synagogues. He concomitantly rejected the notion that Capernaum's Christians and its few Jews co-existed in any mutually influential way. Drawing a comparison with thirteenth-century Jerusalem, in which, according to $\mathrm{Ma}^{\prime} \mathrm{Oz}$, 'one Jewish painter was allowed to reside in Christian Jerusalem', Ma'oz similarly imagined that only a few Jewish fishermen, farmers, and artisans were allowed to live in Capernaum merely as tokens of its Jewish past now under Christian rule (ibid. p. I 44).

In 20I4, Benjamin Arubas and Rina Talgam built largely on Ma'oz's theory but departed from it in several important ways. On the one hand, taking the legal sources at face value and affirming the 'discrepancy' concerning the proximity of the monumental buildings as the central historical problem, they, like Ma'oz, were pushed to view the Capernaum synagogue and its grandeur as a unique case demanding a 'stirring appraisal'. On the other hand, while they, too, ultimately attributed the patronage of the synagogue to outside Roman imperial funding, they differed from $\mathrm{Ma}$ 'oz on two main points. First, they proposed that the funding was mediated specifically through Joseph of Tiberias, known from Epiphanius's Panarion as the famous Jewish convert to orthodox Christianity who was commissioned by Constantine in the second half of the fourth century to build churches in the Jewish towns of Galilee. ${ }^{11}$ According to Arubas's and Talgam's historical construction, Joseph came to Capernaum considerably later than when most scholars date his building activity, some time after the great earthquake of 363 and before Epiphanius took up his position as bishop of Salamis in 367 (Arubas and Talgam 2014: $242-3,245$ ). Adopting Corbo's initial dating of the limestone synagogue to the second half of the fourth century, they hypothesised the existence of an earlier synagogue on the same site that suffered extensive damage during the earthquake. For Arubas and Talgam, Joseph came with an empire-supported offer to Capernaum's Jewish community to fund a massive renovation of the town's synagogue in exchange for approval to build a church, the so-called domus ecclesia of the house of $\mathrm{St}$ Peter, the remains of which were dated to the late fourth century by Corbo and Loffreda. And second, while Arubas and Talgam affirmed that the limestone synagogue was used by the sizeable Jewish community in Capernaum, they asserted on the basis of the reference to the 'sons of Capernaum' as minim in the late Palestinian midrash Qobelet Rabbah I:8 and 7:26 that this community was entirely comprised of what the rabbis

11 On the Joseph episode in Epiphanius's Panarion 30: I I, see Goranson I990, I 999; Ryan 202 I: I 84-20I. 
called minim ('heretics'): non-rabbinic Jews who were sympathetic to Christianity and who worked closely with Christian pilgrims to bring economic prosperity to the village. While, for Arubas and Talgam, the synagogue is fundamental to our understanding of Jewish-Christian relations in Capernaum, the peculiar identity of the town's Jews is made to match the peculiar situation of the grand synagogue erected a stone's throw away from a Christian building.

Although his focus was on identity formation and the architecture of the church and the limestone synagogue rather than the synagogue's source of funding, Anders Runesson suggested that the synagogue 'was not financed by the local population but rather by politically and economically more powerful Jews in Tiberias' (Runesson 2007: 252-3). He was particularly drawn to the idea that the house of the patriarch, even after the fall of the patriarchate in $c .429 \mathrm{CE}$, was behind the building's fifth/early-sixthcentury construction as a way to reassert Jewish - and particularly rabbinic - cultural and political agency through the synagogue's spectacular yet conservative architecture. For Runesson, the synagogue was probably much too large for the actual Jewish population of Capernaum, which he thought justified his argument that external funding and ideology supported the building project. The synagogue, for him, represented an act of defiance in the face of Byzantine colonisation; it reflected Jewish-Christian conflict in the town and, more broadly, the deteriorating relations between a politically empowered Christianity and a colonised yet still influential Jewish community.

In two recent publications, Raimo Hakola (2016, 202 I) has suggested a different paradigm of benefaction not only for the Capernaum synagogue but also for others discovered, some quite recently, in eastern
Galilee. Setting the limestone synagogue in the broader context of recent excavations at the elaborately decorated synagogues of Huqoq, Horvat Kur, and Wadi Hamam, Hakola has challenged the idea that one should approach the grandeur of the Capernaum synagogue as a special case demanding radical solutions or stirring appraisals (Hakola 20I6: I60-I). Hakola has argued that these synagogues, which are roughly contemporary with the Capernaum synagogue, demonstrate that local rural communities in the region could support impressive building projects out of their own resources. Further, Hakola reads the historical sources with suspicion, especially the imperial edicts from the time of Theodosius II and Justinian banning the construction of synagogues, which he sees as an indication that Jewish communities in Byzantine Galilee actually ignored such edicts; indeed, the repeated renewal of such imperial enactments is evidence not of the decline of Galilean Jewish society in this period but rather of its vitality (ibid. pp. I 57-60). The rich archaeological record from fifth- and sixth-century Jewish sites continues to bear this point out. Hakola is not as certain when it comes to the question of wealth generation in these local Galilean towns. He nevertheless proposes a couple of possible sources of income: small-scale agricultural production and, more likely, participation in Byzantine trade networks, which brought money in from wealthy Christian pilgrims (ibid. p. I64). While Capernaum as a site of Christian pilgrimage is important, too, for Hakola in this regard, he does not, as Ma'oz and Arubas and Talgam do, connect Christian wealth to the construction of the limestone synagogue. The synagogue remains an expression of a secure Jewish identity in contrast to the Christian identity projected by the octagonal church (fig. 2). But these buildings tell only part of the story. For Hakola, they need to be 'read' 
sceptically, just like the historical sources, and we should assume that, outside these buildings, Jews and Christians interacted with each other in a variety of ways (ibid. p. I 65).12

\section{Interpreting the dynamics of local and non-local influences on the Capernaum synagogue: methodological issues, neglected sources, and a recent discovery}

Each of the theories and approaches surveyed above has a number of strengths and weaknesses. The likelihood that Capernaum's limestone synagogue was erected in the late fifth or sixth century puts it out of the realm of possibility that Joseph of Tiberias, active in the mid-fourth century, had anything to do with its construction. One must also reckon with the possibility, as Jordan Ryan recently has (Ryan 202I: I90-201), that the 'church' Epiphanius says Joseph built in Capernaum was actually not the late-fourth-century domus ecclesia on the remembered spot of the house of Peter but rather the fourth-century chapel built in nearby Tabgah to commemorate the site of Christ's multiplication of the loaves. Either way, any historical construction of the socio-economic context of the limestone synagogue and Jewish-Christian relations that has Joseph of Tiberias at its centre is on shaky ground.

Theories that posit imperial patronage for the synagogue, whether or not for use as a Christian pilgrimage attraction, run up against a complete lack of evidence. ${ }^{13}$

12 I have recently argued something similar to this specifically for the situation in Capernaum and from the perspective of Michel de Certeau's social theory of everyday life. See Cirafesi 202 Ia.

13 It is certainly true, as Arubas and Talgam assert, that imperial funds were used to build churches in the fourth and following centuries, but there is no evidence that
As Runesson (2007: 253 n. 84) has noted, this dearth is explained rather simply: the Byzantines built churches to commemorate Jesus, not synagogues, since they sought to remember Jesus within the framework of Christianity, not Judaism. It is certainly understandable, however, why scholars would think it necessary to generate such theories, even without any evidence. While, as Hakola has rightly argued, the Capernaum synagogue itself need not be understood as a special case among the monumental synagogues of late ancient Galilee, its broader village context surely does qualify it as a unique phenomenon. Hakola is correct to suggest that sites with grand synagogues, such as Huqoq, Horvat Kur, and Wadi Hamam, are also examples of the remarkable number of resources Galilean Jews could pour into the making of their public buildings during this period. But none of these synagogues, nor any other for that matter, is set twentyfive metres away from a contemporaneous Byzantine church that functioned as a known place of Christian pilgrimage from at least the late fourth century onwards. ${ }^{14}$ In this regard, there is, really, no site directly comparable to Capernaum throughout the entire

imperial funds were ever directed to build synagogues. The example they mention of the ancient synagogue in Nazareth - which, according to Egeria, was converted into a church but, according to the Anonymous Piacenza Pilgrim, continued as a synagogue frequented by Christian pilgrims and the Jewish community - is no solid comparison, since, even if we follow the testimony of the Piacenza Pilgrim (which I am not necessarily convinced we should do), there is no evidence that imperial funds were involved in its construction or preservation in any way.

14 On the likelihood that Christ-following pilgrims began visiting the remembered house of St Peter as early as the third century, see Cirafesi 202 Ib. 
Byzantine East. ${ }^{15}$ Furthermore, the major imperial law codes and Christian theological treatises from the fourth to the sixth centuries do, indeed, reflect a clear anti-synagogue (and anti-Jewish in general) agenda. If these sources are taken at face value, one could understand the allure of the hypothesis that a grand synagogue built in the fifth or sixth century right next to a Byzantine church would have needed the special approval and the special financial backing of the empire itself. This is especially the case if one begins a historical construction from the assumption that Jewish-Christian relations in late ancient Galilee were fundamentally characterised by antagonism and conflict (e.g. Aviam r 999: $28 \mathrm{I}-300)$.

However, without evidence, a hypothesis, even a reasonable one, has little on which to hang its hat. In this respect, Hakola's methodological critique of the imperial funding theory is crucially important. The architecture of Capernaum's monumental buildings confronts us with our hermeneutical assumptions about Jewish-Christian relations in this town and during this time, exposing our historical biases concerning what we believe could or could not have been possible regarding the ways Jews and Christians interacted. Hakola rightly highlights, in not so many words, that architecture, just like literary sources, can

15 Beth Yerah (Khirbet al-Karak), on the southern shore of the Kinneret Lake about $8 \mathrm{~km}$ south of Tiberias, had once been raised as a site comparable to Capernaum. Scholars had once supposed Beth Yerah afforded evidence of a Byzantine church and, about fifty metres to its south, a synagogue encompassed by a Roman fort. Howsever, recent research on the site by Donald Whitcomb has confirmed an Umayyad date for the complex and concluded that the supposed synagogue was actually a type of Umayyad palace, see Whitcomb 2009: 245-6. participate in the politics of identity construction, projecting on one social level static boundaries that simultaneously demarcate group identities and establish for them the security of place. In the attempt to understand the social realia of Jewish-Christian relations on the ground, the iconographies of Capernaum's limestone synagogue and octagonal church need to be 'read' critically. As I have argued elsewhere concerning the situation of late ancient Capernaum, on the basis of the social theory of Michel de Certeau (Cirafesi 202 Ia), everyday life does not play by the same self-segregating rules of strategic power, power that shapes through language and objects the realm of 'the proper', 'the official', and the 'what-should-be-done'. Everyday life, rather, is characterised by the spontaneous manipulation of that realm, chock-full of what de Certeau calls 'tactical actions', which function like soldiers behind enemy lines, creating short-cuts and looking for opportunities to break rules that would otherwise order and partition a society's discrete social identities. Everyday life therefore involves not merely the crossing of identity boundaries but their exploitation.

From this perspective, the architecture of Capernaum's synagogue and church do, indeed, project boundaries between the identities of distinct social groups. I concur with Hakola, however, in questioning whether we should see this boundary-making as striking, in need of special explanation, or as indicative of conflict between the town's Jewish and Christian populations. Manifestations of strategic power always raise the question of how the boundaries it establishes are negotiated and manipulated in everyday life. Thus, if we read the historical sources - such as the anti-synagogue edicts found in the codes of Theodosius II and Justinian and in the ecclesiastical laws of the Canons of the Apostles (see Linder 1987, 1997) - with a hermeneutic 
of suspicion, then we actually gain a window into how some Jews and Christians in eastern parts of the empire engaged in such negotiation. Edicts forbidding the building of new synagogues imply that some Jewish communities were, in fact, erecting new synagogues. That several of the canons prohibit activity ranging from Christians entering a synagogue to pray with Jews, to Christians co-celebrating Sabbaths and Jewish holidays (especially Unleavened Bread) ${ }^{16}$ and providing oil to synagogues for lamp-lighting rituals, likewise implies that Christians were performing such activities on the social level

16 See e.g. Linder I 997: nos. 3, I 2 I, I 24. This anxiety about the Christian co-celebration of Jewish holidays (including the Sabbath) in synagogues in the sixth century goes back several centuries. Indeed, in the second and third centuries, Origen, for example, tells his gentile Christian audience not to discuss in church questions they had heard raised in synagogue the day before, that is, on the Sabbath (Homiliae in Leviticum 5.8; Selecta in Exodum I 2.46). This implies, of course, that members of his congregation were observing the seventh day by attending synagogue. In late-fourthcentury Antioch, John Chrysostom whose anti-Jewish homilies and treatise Adversus Iudaeos clearly influenced the development of canon law in the Christian East (perhaps even the Canons of the Apostles specifically and its interpretation in the medieval period; see e.g. Linder I 997: no. 353, where 'Johannes Golden Tongue' is mentioned explicitly by a medieval jurist in his commentary on Canon 65) - decried the fact that there were many Christians in his Antiochene congregation that 'fast on the same day as the Jews, and keep the Sabbaths in the same manner' (Homiliae in epistulam ad Galatas commentarius $\mathrm{r}: 7)$. On Chrysostom's portrait of Christian attraction to synagogues on Jewish holidays, see Levine 2005: 295-6; and Wilken I983: $92-4$. of everyday life. ${ }^{17}$ Canons 65,70 , and 7I are good examples:

If a cleric or a layman should enter a synagogue of the Jews or of heretics for prayer, he shall be deposed and excommunicated. $\left(\right.$ Canon 65) ${ }^{18}$

If a bishop or another cleric should fast with the Jews or celebrate holidays with them or accept their festive gifts, such as unleavened bread and anything similar to this, he shall be deposed; if a layman, excommunicated. (Canon 70)19

If a Christian should contribute oil to a temple of the gentiles or to synagogue, or light lamps on their holidays, he shall be excommunicated. (Canon 7 I $)^{20}$

Such sources, and others like them, suggest that we need not resort to a theory of Christian imperial funding for a monumental synagogue for us to imagine that Jews and Christians interacted closely and that their identities were entangled in complex ways. While Arubas and Talgam read the story

17 See e.g. Linder I 997: nos. 2, 4, I03, I05, I IO, I I 6, I 20, I 22, I38, I 77, 354, 355, 948, 950.

18 The Greek text (from Linder I 997: no. 2)

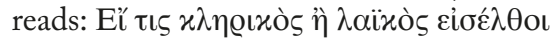

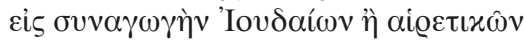

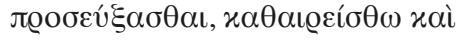

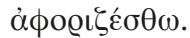

19 The Greek text (from Linder I 997: no. 3)

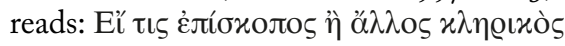

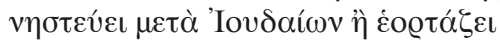

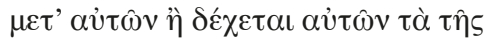

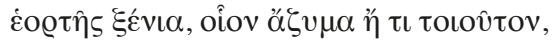

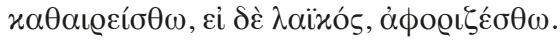

20 The Greek text (from Linder I 997: no. 4)

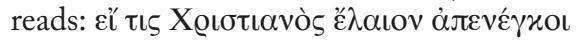

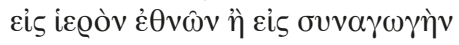

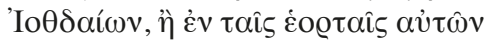

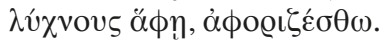


of the Capernaum minim in Qobelet Rabbah too positivistically and leaned too heavily on it in their historical construction, they were right to see the midrash as evidence of the larger discursive endeavour of negotiating the entanglement of Jewish and Christian identities, identities that, for some, overlapped and intertwined and, for others, clashed. Where, in my view, Arubas and Talgam have gone too far is in asserting that the entwinement of Jewish and Christian identities in Capernaum is necessarily evidence for the imperial funding of the limestone synagogue. This assertion exposes, however, a historical assumption in their theory, that dynamic, constructive, and intensely interactive Jewish-Christian relations were an exceptional phenomenon in the Byzantine East and, therefore, ought to lead us to conclude that the economic circumstances surrounding the construction of the limestone synagogue were exceptional as well. But if it was relatively unsurprising to see Christians in Jewish spaces and Jews in Christian spaces, ${ }^{21}$ as I suggest it was (see also Cirafesi 202 Ia), then there is no need to posit a 'radical solution' or a 'stirring appraisal' for the socio-economic circumstances of the limestone synagogue. In other words, imagining close, flexible, and fluid JewishChristian relations in Capernaum does not immediately imply that the Jewish community lacked the power to project their own sense of identity or needed the emperor's money to fund their public building projects. To the contrary, this assumption significantly

21 On Jews in Christian spaces in the fifth century, see Fredriksen 2008: 399 n. 24. There she cites Canon 84 from the Fourth Council of Carthage in 436 CE: 'A bishop may not prohibit anyone - whether a pagan, a heretic, or a Jew - from entering into the church and hearing the word of God; any may stay until the catechumens are sent out.' underestimates the exercise of Jewish cultural and political agency in a time and place for which the archaeological evidence, especially related to synagogues, has increasingly suggested precisely the opposite, that Jews asserted such agency frequently and vociferously (see Levine 2005, 2012; Hakola et al. 202 I: 7-34).

That local Galilean Jewish communities, such as the one in Capernaum, could boldly assert their identities in the midst of their entangled relations with Byzantine Christians does not mean, however, that these communities were entirely economically self-sufficient. The comparative data from Huqoq, Horvat Kur, and Wadi Hamam, while certainly demonstrating the social and cultural vitality of these communities in late Antiquity, do not render conclusive evidence on this front. While inscriptions on mosaic pavements from Horvat Kur, Wadi Hamam, and possibly Huqoq do, indeed, seem to suggest that local donors contributed to parts of the synagogues, these inscriptions are far from evidence that the total economic burden of these buildings was borne at the local level. 22

22 At Horvat Kur, a short Aramaic inscription mentioning a certain 'El'azar son of Yudan son of Susu (or Qoso/Qusu)' is set above the remains of what was probably a depiction of a menorah (Zangenberg 201 7 : I I 4). Nothing in the inscription is said specifically about a contribution from this person, but Jurgen Zangenberg is right that it is plausible that the individual 'had contributed to the community, its synagogue, or the floor and was honored with this inscription' (ibid. p. I I 4). Of course, if this individual was a donor, he almost certainly did not fund the entire building but rather, as was more common, donated to a specific architectural element within the synagogue (see Levine 2005: 386-7 for examples). The mosaic panel with the menorah seems 
In my view, we should think similarly about the case of the Capernaum synagogue. On the one hand, although not receiving any comment in the historical scholarship surveyed above, two donor inscriptions were found on individual columns belonging to the period of the limestone building (fig. 4). While one was carved in Greek and the other in Aramaic, both share a similar donor formula, which mentions (at least) three family generations and the contribution of a column to the synagogue. ${ }^{23} \mathrm{~A}$ man named Herod and his son
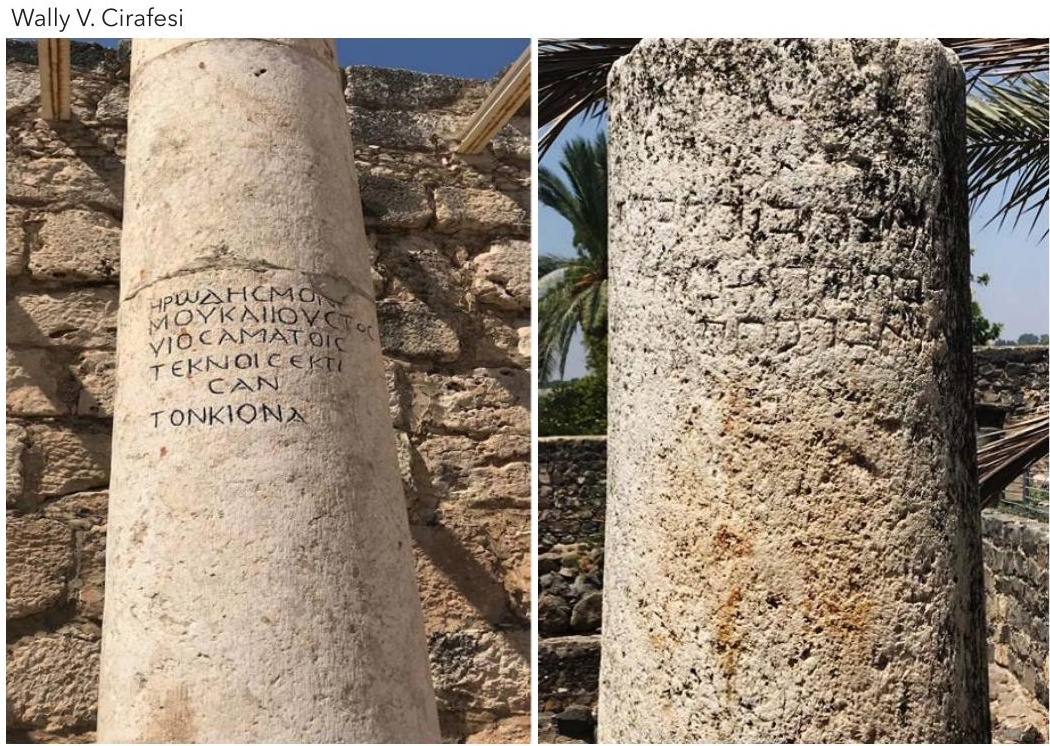

Fig. 4. Left: Donor inscription in Greek on column from the limestone synagogue. The inscription reads: 'Herod, son of Mo[ni]mou, and Justus (his) son, together with the children, erected the column.' Right: Donor inscription in Aramaic on column from the limestone synagogue. The inscription reads: 'Halifu/o, son of Zebidah, the son of Yoḥanan, made [i.e., donated] this column.'

Justus are the primary donors in the Greek inscription; Halfu/o is the donor named

to be the most likely candidate. Analogously, the donor inscription in Panel I I in the western aisle of the Wadi Hamam synagogue states: 'The sons of Simon made [i.e., donated] this panel from their own [means]' (translation from Leibner and Miller 20 Iо: 249). An inscription found in the 'Commemorative Panel' in the Huqoq synagogue (see Magness et al. 20 18: 96-7) might also function to bless those who made charitable donations to the construction or repairs of parts of the synagogue. No named individuals seem to be mentioned. However, as Magness et al. note, the mosaic and its inscription are fragmentary and difficult to interpret, so no firm conclusions can be drawn at this point.

23 The Greek inscription reads in translation: 'Herod, son of Mo[ni]mos, Justus his son, together with the children, erected this column' (trans. slightly adapted from Loffreda 1993). The Aramaic inscription reads in translation: 'Halifu/o son of Zebidah, son of Yohanan, made this column. May he be blessed' (trans. slightly adapted from Loffreda I993). in the Aramaic inscription. Furthermore, a sixth-century donor inscription found on the mosaic pavement of the Hamat Gader synagogue (see note 4 ) names, among others, a certain 'Yosse bar Dosti from Capernaum' as a monetary contributor to that building (fig. 5). There is no reason to doubt that all of these donors were Jewish and that they and their families were local to Capernaum. ${ }^{24}$

24 On the names given in both inscriptions, see Ilan 20r 2. On the high probability that these donors were local, see Levine 2005 : 373, where he notes: 'As might be expected, donors were almost always members of the local community.' Interestingly, he lists the donor inscription from Hamat Gader as an exception, in which non-local inhabitants donated to a synagogue building, with donors hailing from Sepphoris, Arbel, Capernaum, Emmaus, and Kefar 'Aqavia. The fact that the characteristic blessing 'May the King of the Universe extend a blessing upon their works' - comes after the mention of the donors and the sums of their contribution, to my mind, severely hinders Arubas's and Talgam's theory 


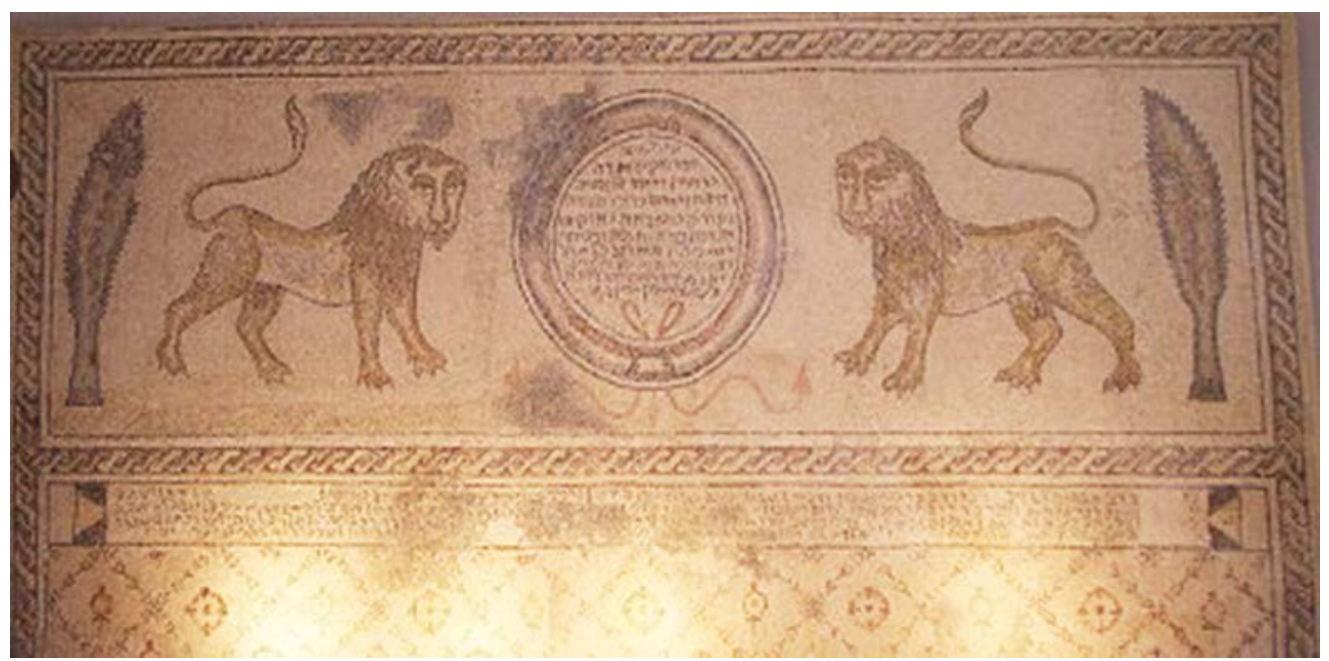

Fig. 5. Donor inscription (beneath the lion panel) on the mosaic floor of the Hamat Gader synagogue (6th century). Public use of this image is licensed under the CC BY-SA 3.0.

We are, therefore, on quite solid ground in claiming that Capernaum's Jewish population possessed a level - perhaps even a significant level - of internal wealth, which could have been directed towards the construction of the synagogue. The question, of course, is whether there was enough wealth to sustain a building project that, according to Loffreda, from start to finish lasted almost a century (Loffreda I997: 232-3).

(20 I4: 246) regarding this Yosse bar Dosti from Capernaum. They suggest that the Hamat Gader inscriptions is inconsistent with Qobelet Rabbah, since 'no synagogue would accept the donation of a heretic (or at least the heretic would attempt to hide his identity in some way)'. They conjecture that Yosse bar Dosti's donation may have been so large that the Hamat Gader community could not have refused it; or that the donation was made in an attempt to clear Capernaum's bad name. It seems to me that Arubas and Talgam wrongly allow the highly ideological midrash to dictate the interpretation of the inscription, for it is just as likely, or even more so, that Capernaum's Jews were simply not considered minim (as some rabbis asserted) by other (non-rabbinic) Jews.
On the other hand, the impulse from some scholars to posit some kind of external support also has evidence in its favour and is now further supported by a recent archaeological discovery. First, even if Hamat Gader was a special attraction in the region owing to its hot springs, the inscription on the floor of its synagogue mentioning donors from all around Galilee shows that local Jewish communities, and specifically Capernaum, had socio-economic networks in place from which to draw and to which to contribute. The flow of money and resources, human and material, does not appear to have been static, controlled only by the urban elite, or confined to isolated towns and villages but rather was dynamic and relatively diffuse, and operated with a strong sense of trans-local social connectivity. ${ }^{25}$ In other words, late

25 For example, the same craftspeople and artisans could work in multiple towns and on multiple synagogues. Lee Levine (2005: 373) notes a father and son pair who laid the mosaic floors in the synagogues of Beth Alpha and Beth Shean, and another artisan who worked in 'Alma and Bar'am in the Upper Galilee. Town marketplaces 
ancient Galilee was not a rural backwater. As Sharon Mattila has recently shown, villages and villagers were engaged in high levels of market exchange, with relative sophistication and access to wealth (Mattila 20 I 4: 3 I 2-45). As Hagith Sivan has noted (2008: 46-7), the rise of Christian pilgrimage to the region certainly contributed to this general state of prosperity in the first half of the sixth century, but it would be a mistake to say Christian pilgrimage was the only factor generating this wealth. Village life, as Mattila puts it, was a much more 'diverse and complex phenomenon', and one could easily apply this description to the nature of Jewish-Christian relations in late ancient Galilee as well.

Second, the studies of $\mathrm{Ma}$ 'oz and Runesson have highlighted that the limestone materials used in the construction of the synagogue must have been imported from outside Capernaum (Ma'oz I999: I39; Runesson 2007: 239, 252-3), from a site, as Ma'oz says, no less than ten kilometres away, such as Mout Arbel. Ma'oz goes on to assert that 'The import of building material from outside sources is not recorded at any other Galilean synagogue, and it is extremely rare even in the excavated areas of Tiberias' (Ma'oz I999: I39). Ma'oz presumed this point supported his overall theory of Christian imperial involvement in the construction of the

(called in rabbinic literature the shuk) could bring in a significant level of out-of-town foot-traffic and generate notable economic gain. Note what Cynthia Baker says about the shuk in late-ancient Galilee: '[It was] the chief locale for commerce in goods, services, and information of all sorts. It is ... that place where all manner of people of local, distant, and foreign origin had access to one another, as well as to goods that were similarly of local, distant, and foreign origins' (Baker 2002: 105). Capernaum's shuk comprised of house-shops that lined the major north-south road (see $\mathrm{L}_{39}$ in fig. 3). See Mattila 201 5: 224 (her 'Fig. D'). limestone synagogue. Runesson, however, was led to theorise that it demonstrated the involvement of wealthy Jews in Tiberias.

In late 20 I $_{5}$, Runesson's theory received a boost. During excavations at Kursi Beach, ${ }^{26}$ led by Haim Cohen and Michael Artzy of the University of Haifa, a marble slab with a dedicatory Aramaic/Hebrew inscription dating to circa the fifth century was discovered on the floor of a synagogue. The inscription was first published in 2016 in the Journal of the Jesus Movement in its Jewish Setting (JJMJS). ${ }^{27}$ Not only does the inscription confirm the existence of a Jewish population in Kursi contemporaneous with its Christian one, but it also seems to confirm, pace Ma'oz's earlier assumption, that building material could, indeed, be imported from an outside source. Although fragmentary in places, the inscription clearly mentions a donation to the Kursi synagogue from an individual 'from Tiberias' (דמן טיבריה). The statement in lines $2-3$ of the donor (the name is fragmentary/indiscernible) 'who contributed marble (מרמריה) 28 for the honor of (this) holy [place]'29 does not appear to be a reference merely to the marble tablet itself but to a general contribution of marble that was, perhaps, used in architectural elements throughout the synagogue. As the excavators judiciously note, since the synagogue has not been fully excavated, it is impossible to know this with any certainty

26 Kursi is an archaeological site on the eastern shore of the Lake of Galilee near the foothills of the Golan Heights. Since the fifth century, it has been known as a Christian pilgrimage location and as home to Galilee's largest monastic complex.

27 Open access to the publication (and all of JJMJS's publications) can be found at <jjmjs.org> (Misgav et al. 2016: I67-9).

28 Jastrow I 903: s.v. מרמירא.

29 Translation by the excavators in Misgav et al. 2016: 168. 
(Misgav et al. 2016: I69). Nonetheless, marble, as a high-demand yet non-natural resource in Palestine, was quarried and imported from all over the Mediterranean world to the major cities of the region (Fischer 2007: 249). It was apparently masoned by associations of marble-cutters in these cities, including in Tiberias, ${ }^{30}$ but it took individuals with financial means - like the Tiberian mentioned in the Kursi synagogue inscription - to fund the transport of dressed marble to local villages. Thus, no matter the actual extent of the marble's use in the Kursi synagogue, the inscription encourages us to imagine a dynamic socio-economic network in place during the fifth and sixth centuries, a network that both connected Jewish communities to one another and involved them in the broader complex currents of commercial activity throughout the Byzantine Empire.

\section{Conclusion: towards a more complex historical construction}

The socio-economic context of Capernaum's limestone synagogue was clearly complicated and multi-faceted. In my view, we are safe to rule out Christian imperial involvement in the construction of the building, but there is, indeed, evidence that supports the idea of both local and non-local Jewish patronage. The best historical conclusion to draw, therefore, might be that a dynamic duo of both internal and external funding was behind the project: on the one hand, local residents, made relatively wealthy from their participation in vibrant commercial networks active

30 See Levine 2005: 373 n. 285 , where he cites an inscription from Tiberias stating 'May God's grace be with Abraham the marble-cutter'. Yitzhar Hirschfeld (2005: 34) notes that this inscription was found engraved on the capital of a synagogue pillar. throughout Byzantine Galilee; and, on the other hand, supportive non-residents within the broader social network of Capernaum's Jewish community. We can, therefore, imagine an inner-communal effort of modest donations from average wage-earners in the village supplemented by major contributions from individual families, such as those of Herod, Halifu/o, and Yosse bar Dosti. This internal funding could then have been supported by wealthy donors from towns and cities around the Galilee, such as Tiberias, Sepphoris, and Beth Shean.

Relations between Jews and Christians in fifth- and sixth-century Capernaum, I suggest, mirrored the dynamic, interactive, and fluid socio-economic context of its synagogue. There is obviously no way to know with any certainty the specific kind of boundary-exploiting activities in which Capernaum's Jews and Christians might have engaged. Capernaum had a particular cultural and commercial attachment to Syria, specifically Antioch, ${ }^{31}$ which, as I have argued elsewhere, might have brought the village's residents within earshot of the harsh prohibitions on Jewish-Christian interaction given in the sixth-century Antiochene edition of the Canons of the Apostles (see Cirafesi $202 \mathrm{Ia}$ ). As mentioned in several examples from the Canons given above, activities such as Jews and Christians praying in each others'

31 See Loffreda I 993: I8-I 9, where he points to the numismatic record, imported vessels, and the town's proximity to an imperial highway that ran directly to Damascus as evidence. We can also note the discovery of Syriac graffiti in the late-fourth- to midfifth-century remains under the octagonal church as a significant religio-cultural connection as well. Mattila 2015:25 I also lists Antioch, specifically, as one of the major eastern centres to which Capernaum villagers seemed to have had close economic ties. 
sacred buildings, contributing oil for lamplighting rituals, 32 and sharing festive meals are prohibited and severely condemned. ${ }^{33}$ All

32 The locus labelled Li I 9 in fig. 3, situated just off the NE corner of the synagogue, has been identified as an oil-lamp/pottery shop (for description of this 'bottega', see Corbo I975: 207).

33 Christian participation in Jewish healing practices might be added to this list of potential tactics. One point that Levine makes in commenting on John Chrysostom's Adversus Iudaeos is that Christian attraction to synagogues seems to have been, in part, due to the 'powers' believed to be linked to Jewish healing procedures, procedures which themselves were closely connected in the ancient world to magical practices such as incantation and amulet texts (Levine 2005: 295). There are many sources now known that demonstrate that Jews in late Antiquity were involved in this realm, and several canons of the Church indicate that Christians routinely went to the Jewish community for healing and medical attention (e.g. Canon I I of the Council in Trullo, 692 CE: 'No one of those enlisted in the sacerdotal order, nor a layman, should eat the unleavened bread of the Jews, or associate with them, or call on them in sickness and receive from them medicines, nor bathe with them in baths. If anyone should attempt to do this, if a cleric, he shall be deposed; if a layman, excommunicated' [Linder i 997: no. I 24]). Among the excavations in Capernaum's Area 5, in the oil-lamp shop adjacent to the NE corner of the synagogue (see Li I 8-I9 in fig. 3), a Greek magical pendent was found with the words $\alpha \gamma \operatorname{los} / \alpha \gamma \operatorname{Los} /$ $\alpha \gamma \operatorname{los} / \mathrm{I} \alpha \omega / v \gamma|<\varepsilon|>\alpha$ inscribed on the obverse and $\pi \iota v \omega / \mathrm{Y} / v \gamma \mathrm{\gamma}<\varepsilon l>\alpha$ inscribed on the reverse ("holy / holy / holy / Iao [i.e., YHWH] / health' and 'I drink health'; for images, see Loffreda 2008: I 20 (DF 863-3I-tI9o); see also Mattila 20I 5: 237. It is impossible to know the specific social context of its use. But it is possible - and this is my conjecture - that this amulet was produced by Capernaum Jews in the oil-lamp/pottery shop near the synagogue but consumed by Capernaum Christians of them plausibly took place in Capernaum. The monumental landscape of the limestone synagogue and the octagonal church certainly established architectural symbols of identity that express the desire to control the movement of its respective subjects. But these buildings also, and at the same time, were drawn into the intense sociality and liminality of Capernaum's everyday domestic landscape; the synagogue and the church cannot be removed from this broader setting. This suggests, to me, that the same spontaneous, opportunistic, and transgressive performance of identities that marked everyday spaces in Capernaum, such as its housing complexes, streets, and marketplace, also marked onthe-ground relations between its Jews and Christians, even if the architecture of the synagogue and the church gave Jewish and Christian identities something concrete on which to hang their hat.

Wally V. Cirafesi (Ph.D., University of Oslo) is Visiting Researcher in the Faculty of Theology at the University of Oslo. He has published on a range of topics related to the study of ancient Judaism and early Christianity, including the Dead Sea

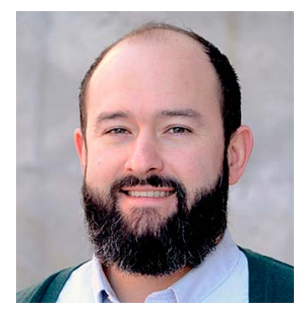

Scrolls, ancient synagogues, churches, and Jewish-Christian relations. He has participated in recent archaeological excavations at Magdala (Galilee), and he is currently working on a major research project on the history of Jews and Christians in Capernaum from the time of Jesus to the rise of Islam in Palestine.

\section{List of references}

who, like Antiochene Christians, 'ran to the Jews to be healed by charms, incantations and amulets' (Adversus Iudaeos 8.5; 935; 8.7; 937-8)' (Wilken I 983: 83-8, here p. 83 and quoting John Chrysostom's Adversus Iudaeos). 
Arubas, Benjamin Y., and Rina Talgam. 2014. 'Jews, Christians, and minim: who really built and used the synagogue at Capernaum: a stirring appraisal', in Knowledge and Wisdom: Archaeological and Historical Essays in Honour of Leah Di Segni, eds. Giovanni C. Bottini, Leslaw D. Chrupala and Yosef Patrich. Studium Biblicum Franciscanum / Collectio maior 54 (Milano: Edizioni Terra Santa), 237-74.

Avery-Peck, Alan J., and Jacob Neusner (eds.). 2001. Judaism in Antiquity, part 3: Where We Stand: Issues and Debates in Ancient Judaism. Vol. 4: The Special Problem of the Synagogue (Leiden: Brill).

Aviam, Mordechai. I999. 'Christian Galilee in the Byzantine period', in Galilee through the Centuries: Confluence of Cultures, ed. Eric M. Meyers (Winona Lake, IN: Eisenbrauns), $28 \mathrm{I}-300$.

Baker, Cynthia M. 2002. Rebuilding the House of Israel: Architectures of Gender in Jewish Antiquity. Divinations: Rereading Late Ancient Religion (Stanford University Press).

Becker, Eve-Marie. 201 5. 'Jesus and Capernaum in the apostolic age: balancing sources and their evidence', in The Mission of Jesus. Second Nordic Symposium on the Historical Jesus, Lund 7-10 Oct. 2012, ed. Samuel Byrskog and Tobias Hägerland, WUNT 2.39 I (Tübingen: Mohr Siebeck), I I 3-39.

Callegher, Bruno. 2007. Cafarnao, vol 9: Monete dall'area urbana di Cafarnao (19682003) (Jerusalem: Edizione Terra Santa).

Chancey, Mark A. 2002. The Myth of a Gentile Galilee. Society for New Testament Studies Monograph Series I I 8 (Cambridge University Press).

Cirafesi, W. V. 202 r a (forthcoming). 'Imagining the everyday life of Jewish and Christian "neighbors" in late antique Capernaum: beyond church and synagogue-and back again', in The Ambiguous Neighbour, ed. M. B. Kartzow. Intersectional Studies in Jewish, Christian, and Muslim Texts and Receptions (London: Routledge).

$202 \mathrm{Ib}$ (forthcoming). 'Jewish Christ-followers in Capernaum before the fourth century? Reconsidering the texts and archaeology', in Negotiating Identities: Conflict, Conversion and Consolidation in Early Judaism and Christianity (200 BCE-400 CE). Journal for the Study of Judaism Supplements, ed. Karin Hedner Zetterholm et al. (Leiden: Brill).
Corbo, Virgilio Canio. I 975. Cafarnao. Vol. I: Gli edifici della città (Jerusalem: Franciscan Printing Press).

Custodia Terrae Sanctae, <https://www.custodia. org/en/sanctuaries/capernaum> (accessed 4.5.202 I).

Fischer, Moshe L. 2007. 'Marble imports and local counterparts: luxury business in Roman Palestine', Topoi: Orient-Occident 8: 249-69.

Foerster, Gideon. I995. 'Dating synagogues with a "basilical" plan and an apse', in Ancient Synagogues: Historical Analysis and Archaeological Discovery. Vol. I, eds. Dan Urman and Paul V. M. Flesher (Leiden: Brill), 87-94.

Fredriksen, Paula. 2008. Augustine and the Jews: A Christian Defense of Jerws and Judaism (New York: Doubleday).

Goranson, Stephen C. r 990. 'The Joseph of Tiberias Episode in Epiphanius: Studies in Jewish-Christian Relations', Ph.D. dissertation, Duke University.

- r 999. 'Joseph of Tiberias revisited: orthodoxies and heresies in fourth-century Galilee', in Galilee through the Centuries: Confluence of Cultures, ed. Eric M. Meyers (Winona Lake, IN: Eisenbrauns), 335-44.

Hakola, Raimo. 2016. 'Galilean Jews and Christians in context: spaces shared and contested in the eastern Galilee in late antiquity', in Spaces in Late Antiquity: Cultural, Theological, and Archaeological Perspectives, ed. Juliette Day et al. (London: Routledge), I 4 I-65.

202 r. 'Galilean synagogues as local responses to cultural globalization in late antiquity', in The Synagogue in Ancient Palestine: Current Issues and Emerging Trends, eds. Rick Bonnie, Raimo Hakola, and Ulla Tervahauta. Forschungen zur Religion und Literatur des Alten und Neuen Testaments 279 (Göttingen: Vandenhoeck \& Ruprecht), $27 \mathrm{I}-88$.

Hakola, Raimo, Rick Bonnie, and Ulla Tervahauta. 202 I. 'The synagogue in ancient Palestine: current issues and emerging trends', in The Synagogue in Ancient Palestine: Current Issues and Emerging Trends, ed. Rick Bonnie, Raimo Hakola and Ulla Tervahauta. Forschungen zur Religion und Literatur des Alten und Neuen Testaments 279 (Göttingen: Vandenhoeck \& Ruprecht), 7-34. Hirschfeld, Yitzhar. 2005. Roman, Byzantine, and Early Muslim Tiberias: A Handbook of Primary Sources (Bloomington, IN: Indiana University Press). 
Ilan, Tal. 20 I 2. Lexicon of Jerwish Names in Late Antiquity. Part 2: Palestine 200-650 CE. Texts and Studies in Ancient Judaism I48 (Tübingen: Mohr Siebeck).

Jastrow, Marcus. I903. A Dictionary of the Targumim, the Talmud Babli and Yerushalmi, and the Mirdashic Literature (Leipzig: W. Drugulin).

Kohl, Heinrich, and Carl Watzinger. 19 16. Die antiken synagogen in Galiläa (Leipzig: J. C. Hinrichs'sche Buchhandlung).

Kuhnen, Hans-Peter. 2014. Kalifenzeit am See Genezareth: Der Palast von Khirbat al-Minya (Oppenehim: Nünnerich-Asmus Verlag \& Media $\mathrm{GmbH}$ ).

Laughlin, John H. C. I989. 'The identification of the site', in Excavations at Capernaum. Vol. I: 1978-1982, ed. Vassilios Tzaferis (Winona Lake, IN: Eisenbrauns), I 9I-9.

Leibner, Uzi, and Shulamit Miller. 20 ro. 'A figural mosaic in the synagogue at Khirbet Wadi Hamam', Journal of Roman Archeology 23: 238-64.

Levine, Lee I. 2005. The Ancient Synagogue: The First Thousand Years, 2nd edn (New Haven, CT: Yale University Press).

-20 2. Visual Judaism in Late Antiquity: Historical Contexts of Jewish Art (New Haven, CT: Yale University Press).

Linder, Amnon. 1987. The Jerws in Roman Imperial Legislation (Detroit, MI: Wayne State University Press).

- i 997. The Jerws in the Legal Sources of the Early Middle Ages (Detroit, MI: Wayne State University Press).

Loffreda, Stanislao. 1973. 'The late chronology of the synagogue of Capernaum', Israel Exploration Journal 23(I): 37-42.

I 993 . Recovering Capharnaum. SBF Guides I (Jerusalem: Franciscan Printing Press).

_ r 997. 'Coins from the synagogue of Capernaum', Liber Annuus 47: 223-44.

2005. Cafarnao. Vol. 5: Documentazione fotográfica degli scavi (1968-2003) (Jerusalem: Edizione Terra Santa).

2008. Cafarnao. Vol. 8: Documentazione fotografica degli oggetti (1968-2003) (Jerusalem: Edizione Terra Santa).

Magness, Jodi. 200 I. 'The question of the synagogue: the problem of typology', in Judaism in Antiquity. Part 3 / vol. 4: Where We Stand: Issues and Debates in Ancient Judaism: The Special Problem of the Synagogue, ed. Alan J. Avery-Peck and Jacob Neusner (Leiden:
Brill), $\mathrm{I}-48$.

-2OI 2. 'The pottery from the village of Capernaum and the chronology of Galilean synagogues', Tel Aviv 39: I Io-22.

Magness, Jodi, et al. 20 18. 'The Huqoq Excavation Project: 20I 4-20I 7 interim report', Bulletin of the American Schools of Oriental Research 380: 6I-I3I.

Ma'oz, Z.U. r 999. 'The synagogue at Capernaum: a radical solution', in The Roman and Byzantine Near East. Vol. 2: Some Recent Archaeological Research, ed. John H. Humphrey. Journal of Roman Archaeology Supplements 3I: $137-48$.

Mattila, Sharon L. 20I4. 'Inner village life in Galilee: a diverse and complex phenomenon', in Galilee in the Late Second Temple and Mishnaic Periods. Vol. г: Life, Culture, and Society, eds. David A. Fiensy and James R. Strange (Minneapolis, MN: Fortress Press), 3 I $2-45$.

-2015. 'Capernaum, village of nahum, from Hellenistic to Byzantine times', in Galilee in the Late Second Temple and Mishnaic Periods. Vol. 2: The Archaeological Record from Cities, Towns, and Villages, ed. David A. Fiensy and James R. Strange (Minneapolis, MN: Fortress Press), 2 I 7-57.

Misgav, Haggai, Michal Artzy, and Haim Cohen. 2016. 'The synagogue inscription from Kursi', Journal of the Jesus Movement in its Jewish Setting 3: 167-9.

Naveh, Joseph. 1978. On Stone and Mosaic: The Aramaic and Hebrew Inscriptions from Ancient Synagogues (Jerusalem: Israel Exploration Society).

Reed, Jonathan L. 2000. Archaeology and the Galilean Jesus: A Re-examination of the Evidence (Harrisburg, PA: Trinity Press International).

Robinson, Edward. 1841. Biblical Researches in Palestine, Mount Sinai, and Arabia Petraea: A Journal of Travels for the Year 1838 (London: John Murray).

I 856. Later Biblical Researches in Palestine and the Adjacent Regions: A Journal of Travels in the Year 1852 (London: John Murray).

Runesson, Anders. 2007. 'Architecture, conflict, and identity formation: Jews and Christians in Capernaum from the first to the sixth century', in Religion, Ethnicity, and Identity in Ancient Galilee, eds. J. Zangenberg, H. W. Attridge, and D. B. Martin. Wissenschaftliche Untersuchungen zum Neuen Testament 2 IO (Tübingen: Mohr Siebeck), 23 I-57. 
Ryan, Jordan. 202 I. From the Passion to the Church of the Holy Sepulchre: Memories of Jesus in Place, Pilgrimage, and Early Holy Sites over the First Three Centuries (London: T. \& T. Clark).

Schneider, A. M. r 95 2. 'Hirbet el-minje am see Genesareth', Annales archéologiques de Syrie 2: 23-45.

Sivan, Hagith. 2008. Palestine in Late Antiquity (London: Bloomsbury).

Spigel, Chad S. 2or 2. Ancient Synagogue Seating Capacities: Method, Analysis, and Limits. Texts and Studies in Ancient Judaism I 49 (Tübingen: Mohr Siebeck).

Tarkhanova, Svetlana. 202 I. 'The friezes with the "peopled scrolls" motif in the Capernaum synagogue. Dating by stylistic method and some aspects of the reconstruction', in The Synagogue in Ancient Palestine: Current Issues and Emerging Trends. Forschungen zur Religion und Literatur des Alten und Neuen Testaments 279, ed. Rick Bonnie, Raimo Hakola and Ulla Tervahauta (Göttingen: Vandenhoeck \& Ruprecht), I 95-2 I 8.

Tsafrir Yoram. 1995. 'The synagogues in Capernaum and Meroth and the dating of the Galilean synagogue', in The Roman and Byzantine Near East. Vol. 2: Some Recent Archaeological Research, ed. John H. Humphrey. Journal of Roman Archaeology Suppl. Series I 4 (Ann Arbor, MI: Journal of Romn Archaeology), I 5 I-6 I.

Whitcomb, Donald. 2009. 'From pastoral peasantry to tribal urbanites: Arab tribes and the foundation of the Islamic State in Syria', in Nomads, Tribes, and the State in the Ancient Near East, ed. Jeffrey Szuchman (University of Chicago Press), 24I-59.

Wilken, Robert L. I983. John Chrysostom and the Jews: Rhetoric and Reality in the Late 4th Century (Berkeley, CA: University of California Press).

Wilson, John. I 847. The Lands of the Bible Visited and Described, vol. 2 (Edinburgh: William Whyte and Co.).

Zangenberg, Jurgen K. 20I 7. 'The menorah on the mosaic floor from the late Roman/Early Byzantine synagogue at Horvat Kur', Israel Exploration Journal 67: I I0-26. 